\title{
THE MAIN ROLE OF THE INTERNATIONAL TRIBUNAL IN ACCORDANCE WITH PREVENTING AND REPRESSING INTERNATIONAL CRIMES
}

\section{Denisa Barbu}

\section{Barbu}

Faculty of law and Administrative Sciences, Department of Administrative Sciences, Targoviste Valahia University of Targoviste (ROMANIA) Correspondence: Denisa Barbu, Faculty of law and Administrative Sciences, Targoviste, Sos. Gaesti, nr. 8 - 10, Jud. Dambovita, phone: 0245606048 e-mail: denisa.barbu77@yahoo.com

\section{Astract}

In international criminal law, a great role had the Military Courts at Nuremberg and Tokyo, which on the one hand, contributed decisively in their judgments to the shaping of important institutions of international criminal responsibility of individuals as agents of the State, and on the other hand, have demonstrated the need for permanent and strong international criminal jurisdictions.

Keywords: international crime, International Criminal Court, sentences.

\section{Introduction}

Thus, their judgments were the perfect solution to punish criminals regardless of their citizenship and place of perpetrating international crimes that laid the groundwork for an institutionalized system of prevention and repression of the most serious international crimes - war crimes. However, these ad hoc international courts, have, first of all, a punitive character and then a preventive one for international criminal responsibility.

Considering the serious situations that threaten international peace and security in different countries or even parts of the world, the solution was the establishment of a permanent international criminal jurisdiction, which would have that extra-national and non-territorial character, the latter being an "obstacle" in committing the crimes, because the possibility of equivalence from criminal liability shall be reduced to the maximum.

\section{Sentences of the International Criminal Court}

International Criminal Court (ICC) sentences, as permanent specialized court complementary to jurisdiction with national courts, are designed to play a role in the prevention and suppression for the worst international infractions (international crimes).

This justification can be found in the Act of Incorporation - the Rome Statute - in the Preamble, specifying that individuals (including women and children) have suffered from the atrocities of the 20th century, which have encroached on the peace, security and wellness of all mankind, that the punishment of the perpetrators of international crimes helps prevent these acts and that it is incumbent on every State to exercise its criminal jurisdiction over all persons responsible for perpetrating international crimes.

In the Rome Statute is set out an exhaustive list of culpable acts of greater severity which constitutes international crimes and is punishable in accordance with the Act, such as genocide, crimes against humanity, war crimes, and crime of aggression. ${ }^{1}$ 


\section{THE MAIN ROLE OF THE INTERNATIONAL TRIBUNAL IN ACCORDANCE WITH PREVENTING AND REPRESSING INTERNATIONAL CRIMES}

For example, the first act of the jurisdiction of the ICC, adopted on March 14, 2012 by the Attorney Thomas Lubanga Dyilo², envisages the criminal liability to the group leader of rebellion of the Congolese Patriots Union in the Democratic Republic of Congo, for actions taken during the period of September 2002 - august 2003, during the armed conflict in Ituri region between different ethnic (at least three) groups. ICC sentence refers only to a single international crime, in which the defendant was charged and found guilty, a part of the category of war crimes, conscription and enlistment of children under the age of 15, into armed forces or groups or using them to active participation in hostilities. ${ }^{3}$

The ICC has shown countless times, expressly in the sentence (paragraph 896 for example) that examined the actions of the defendant only in the recruitment or enrolment of children under 15 years, not making the pronouncement to other offences, such as torture or rape and sexual slavery, even if the subjects claimed to be victims of these and the existing material evidence substantiated the alleged violations, because the Prosecutor had not included the accusations, The Court, therefore, in the light of art. 74 of the Statute being unable to rule on the facts and circumstances which were not in the charges presented by the Prosecutor's Office.

Therefore, the first international crime over which the ICC has adopted the sentence of condemnation is the recruitment or enlistment of children under the age of 15 years into armed forces or groups or using them to effective participation in hostilities.

ICC made a statement that these children are vulnerable and have suffered from armed conflict (paragraph 605 for example) the recruitment or enlistment under the minimum age of 15 years in the forces and/or armed groups having long-term adverse repercussions and not predictable for the future of the adults' psycho-emotional state.

Punishing international crimes whose victims are children, fall into the insurance standards, the promotion of international peace and security, standards supported by world States at the broadest scale.

By this sentence, the ICC has done a delimitation of the types of conduct that constitute the international crime objectively analysed, thus, the recruitment in armed forces or groups of children under 15 years of age, constitute forced inclusion of the subjects in the armed groups, and enrolment in the armed groups include assuming (intending voluntarily to be part of the armed forces).

Therefore, the recruitment has a coercive character and enrolment - a voluntary character (paragraph 607, 608 of the Sentence).

However, in the light of the crime analysis, the Court found that there are differences between the notions of recruitment and enrolment (paragraph 618), children are vulnerable and easily influenced, as the character is apparent, and adults are responsible for knowingly enlisting the children under the age of 15 years on armed staff.

As such, the consent of children enrolled is not a legal consent in accordance with the rules recognized by international law in general, as well as of international humanitarian law and international human rights law in particular.

Paragraph 622 of the Sentence shows that the use of children in hostilities requires the participation, in addition to direct participation in combat and the active participation in the fighting, as well as adjacent activities, investigation, intelligence agents, couriers, checkpoints, diversions.

In accordance with paragraphs $870-872$ of the Sentence, children under 18 years (mostly aged 12 years old, being discovered cases of participation of children aged 8-11 years) have been

\footnotetext{
${ }^{1}$ Art. 51 in the Rome Statute.

2 CPI, Situation in Congo Democrat Republic, by Attorney Thomas Lubanga Dyilo, decision on March 14, 2012, published to http://www.icc-cpi.int/iccdocs/doc/doc137938.pdf (accesed on 30.03.2012).

${ }^{3}$ Art. 8 ln. 2 let. e pt. VII of the Rome Statute.
} 
trained in specialized military units of small (approximately 45 members) tasked with ensuring the security of the subjects of the Supreme high command.

The children from Kadogo units were personal guardians of military generals, being instructed to accompany members of commandment, to oversee their security in official duties, but also outside of the exercise. There are also the situations that the military units included the teenage girls of 13 and 14 years old, who "out of military service obligations" were obliged to engage in sexual relations with members of staff (paragraph 874 from the Sentence).

Although in the 624 pages of sentence, ICC does not say expressly and clearly the prevention and repression of the entire international crimes, the prevention and repression of international crimes finds its reflection in analysing the subject of crime and punishable conduct on the part of the International Criminal Court. ${ }^{4}$

The establishment and the work of the ICC itself demonstrates that prevention and suppression of international crime, of increased gravity such as war crimes, where the victim is a special-topic - the child, is one of the fundamental functions of international criminal jurisdiction.

This function acquires a special significance concerning the ICC, given the fact that the ICC is the only court of criminal jurisdiction in the world at the present time. Of course, the ad-hoc international criminal tribunals contributed substantially to the promotion and realization of the function of repression and prevention of the most serious crimes worldwide, but utterly ICC has its role in building an international society conscious of the irreversible consequences of international crimes.

Through ICC pronouncement and subsequent implementation of the provisions of the conviction (14 years imprisonment), they based legally and praxeologically the function of repression and prevention of international crimes, demonstrating an active role of the ICC as an International umpire, and not one latent, as some jurists and doctrinal people have assigned until recently.

A particular role for prevention and repression of crimes was attributed to international judicial laws handed down by ad-hoc courts of criminal international jurisdiction.

Thus, by resolution 827 of the UN Security Council of 25 May $1993^{5}$ stipulates that the establishment of the International Criminal Tribunal for the former Yugoslavia (ICTIu) aims to stop committing such crimes and prosecuting persons guilty of committing them. Thus, art. 1 of the Statute of ICTIu provides that it has jurisdiction to prosecute persons responsible for serious violations of international humanitarian law committed in the territory of the former Yugoslavia since 1991.6

Thus, in this optic, the documents to be handed down by ICTIu highlight the repression of atrocities committed by persons who, in a secondary way point to general deterrence (addressed to an undeterminable abstract subject) and special prevention (addressed to a determinable subject in the conflict zone).

For instance, in the judgment of 6 September $2011^{7}$ pronounced by ICTIu, the Serbian General, Chief of the General staff of the Yugoslav Army, Momĉilo Perisicic was found guilty of committing crimes during the siege of Sarajevo, favouring the crimes in Zagreb, instigating and assisting the serious crimes committed in Srebrenica (excepting the crime of mass extermination of Bosnian Muslim population).

${ }^{4}$ D. Sârcu, Rolul actului jurisdicţional internaţional in cultură şi civilizaţie românească, 2013, nr. 1-12, p. 23

${ }^{5}$ Resolution CS ONU no. 827, adopted at 25 May 1993, published on http://www.icty.org/x/file/Legal\%20Library/Statute/statut 827_1993_fr.pdf (accessed on 7.11.2011).

${ }^{6}$ The Statute of the International Criminal Tribunal for former Iugoslavia, the latest amendaments of September 2009 published on http:/www.icty.org/x/files/Legal\%20Library/statute_sept09_fr.pdf (accessed on 08.12.2011).

${ }^{7}$ Prosecutor v. Momciilo Perisiic, the judgment of ICTIu, 6th September 2011, published on http://www.icty.org/x/cases/perisic/tjug/en/110906judgement.pdf (accessed on 09.05.2012). 
THE MAIN ROLE OF THE INTERNATIONAL TRIBUNAL IN ACCORDANCE WITH PREVENTING AND REPRESSING INTERNATIONAL CRIMES

Momĉilo Perisicic was found guilty of committing crimes during the siege of Sarajevo, favouring the crimes Zagreb, instigating and assisting the serious crimes committed in Srebrenica (excepting the crime of mass extermination of Bosnian Muslim population). Momĉilo Perisiic was found guilty ICTIu, for committing crimes against humanity (murder, inhumane treatment, persecution on political, racial or religious reasons) and crimes of infringement of the rules and practices of the war (murder, attacks on civilian populations) and sentenced to 27 years in prison.

\section{Conclusions}

As such, undeniably, this sentence contribute to the prevention and suppression of international crimes, such as crimes against humanity, thus, the sentences issued by international criminal courts, perpetuates an absolutely special significance, given the international climate, in particular with regard to the current massive violations of human rights and fundamental freedoms in the near and Middle East States and beyond.

\section{Bibliography}

1. D. Sârcu, Rolul actului jurisdicţional internaţional in cultură și civilizaţie românească, 2013, nr. $1-12$

2. CPI, Situation in Congo Democrat Republic, by Attorney Thomas Lubanga Dyilo, decision on March 14, 2012, published to http://www.icc-cpi.int/iccdocs/doc/doc137938.pdf (accesed on 30.03.2012).

3. Prosecutor v. Momcilo Perisic, the judgment of ICTIu, 6th September 2011, published on http://www.icty.org/x/cases/perisic/tjug/en/110906judgement.pdf (accessed on 09.05.2012).

4. The Statute of the International Criminal Tribunal for former Iugoslavia, the latest amendaments of September 2009 published on http:/www.icty.org/x/files/Legal\%20Library/statute_sept09_fr.pdf (accessed on 08.12.2011).

5. Rome Statute -1998.

6. Resolution CS ONU no. 827, adopted at 25 May 1993, published on http://www.icty.org/x/file/Legal\%20Library/Statute/statut827_1993_fr.pdf (accessed on 7.11.2011). 